\title{
SOME MEDICINAL PLANTS OF NORTH 24 PARGANAS DISTRICT OF WEST BENGAL (INDIA)
}

\author{
Dolly Saha ${ }^{1}$, T. K. Sarma ${ }^{2}$ and Sobhan Kr. Mukherjee ${ }^{3}$ \\ ${ }^{1}$ Department of Botany, Acharya Jagadish Chandra Bose College, Kolkata, West Bengal, India; \\ ${ }^{2}$ Department of Botany, Bangabasi College, Kolkata, West Bengal, India; \\ ${ }^{3}$ Department of Botany, University of Kalyani, Nadia, West Bengal, India.
}

\begin{abstract}
The district of the North 24 Parganas forms a part of the South-Western portion of the Presidency Division of West Bengal. It extends over $4090 \mathrm{sq} . \mathrm{km}$. The head-quarter is situated at Barasat, established on December 1995. Present study deals with 65 medicinal plants of this district. Their uses in field observation and from authentic literature and their abundance have been incorporated in details. Present study recorded that all together 65 plant species with medicinal properties have been recorded and study has been carried out in detail from Nilgunj, Jagaddal, Thakurnagar, Bisharpara-Kodalia and Bamungachi of the North 24 Parganas district. All the herbarium specimens were kept in G.C. Bose Herbarium, Bangabasi College, Kolkata -700 009, West Bengal, India. The study was conducted by personal interview with the village people and local medicine men (Kabiraj and Hakim). They helped us providing some information according to their knowledge and experiences, about the medicinal uses of the local flora.The information collected by interviewing from the local medicinal men need clinical study for confirmation whether they are effective or not and conserve them scientifically in their original habitat. At the same time the rare plants like-Andrographis paniculata, Crotalaria verrucosa, Derris indica, Hemidesmus indicus, Hygrophila phlomoides, Smilax glabra, S. prolifera, Stephania japonica and Terminalia arjuna of the studied area of North 24 Parganas district need conservation and also can be recommended for plantation due to their important medicinal values.
\end{abstract}

\section{KEY WORDS}

Medicinal Plants, North 24 Parganas district, West Bengal, India.

\section{Introduction}

Though we are living in the age of synthetic drugs the uses of Crude drugs or Ayurvedic medicine are increasing day by day. The synthetic drugs are not only costly but also have some side effects. A vast population of our country living in the villages and they are belonging to backward classes of poor people and they are solely depending on the Ayurvedic medicine. Sometimes urbanized intelligentsia also depends and prefers Ayurvedic medicine to alleviate their ailments because only to avoid the undesirable side effects of modern synthetic drugs. Due to the unscientific random use of plant wealth, they are facing threat. Hence, for the sake of mankind it is now become necessary to survey and to conserve the medicinal plants scientifically in their original habitat.

The district is bounded on the North by Nadia district and a portion of Bangladesh (Khulna division), on the East by Bangladesh, on the South by the district of South 24 Parganas and Kolkata, and on the West by the river of Hooghly, 
which proceeding from North to South, separates it from the districts of Hooghly and Howrah. It extends over 4090 sq. km. The head-quarter is situated at Barasat, established on December 1995.

Present work:

During this survey, all together 65 plant species with medicinal properties have been recorded and studied in detail from Nilgunj, Jagaddal, Thakurnagar, Bisharpara-Kodalia and Bamungachi of the North 24 Parganas district. All the herbarium specimens are kept in G.C. Bose Herbarium, Bangabasi College, Kolkata -700 009, West Bengal, India.

The frequency of the species in the studied area is considered as number of species present per 100 sq.mt. and they are indicated as: Abundant (more than 100 species), Common (more than 50 species but less than 100 species), Occasional (more than 25 species but less than 50 species) and Rare (less than 25 species).

\section{Materials and Methods:}

There is no particular record on medicinal plants of the district but Ambasta et al (1993), Bhattacharya et al (1997), Dey (1896), Hazra et al (1995), Kirtikar and Basu (1918), Sharma et al (1993), Sivarajan and Balachandran (1994), Warrier et al (1993) have worked on medicinal plants of India.

The study was conducted by personal interview by the first author with the village people and local medicine men (Kabiraj and Hakim). They helped us providing some information according to their knowledge and experiences, about the medicinal uses of the local flora.

Observations and Results:

A list of medicinal plants available from the district along with their medicinal values is provided in the following tables: 
Table I: Showing the systematic evaluation of plants, their uses and nature of distribution

\begin{tabular}{|c|c|c|c|c|c|}
\hline \multirow[t]{2}{*}{ Name of the Plant } & \multirow[t]{2}{*}{ Local name } & \multirow[t]{2}{*}{ Family } & \multicolumn{2}{|l|}{ Medicinal Value } & \multirow{2}{*}{$\begin{array}{l}\text { Frequency in the } \\
\text { area under } \\
\text { consideration }\end{array}$} \\
\hline & & & From References & Local uses & \\
\hline $\begin{array}{l}\text { 1. Achyranthes aspera Linn. Sp. } \\
\text { Pl.204.1753 }\end{array}$ & Apang & Amaranthaceae & $\begin{array}{l}\text { Decoction of herb diuretic, used } \\
\text { in renal dropsy. The crushed } \\
\text { plant has been boiled in water } \\
\text { and is given in pneumonia. }\end{array}$ & $\begin{array}{l}\text { The seeds are soaked in water } \\
\text { and the water then taken as } \\
\text { laxative. }\end{array}$ & Abundant \\
\hline $\begin{array}{l}\text { 2. Adhatoda zeylanica Medic. } \\
\text { Hist and Commentant. Acad. } \\
\text { Elect. Sci. Theod. Plat. } 6 \text { : } 393 . \\
\text { 1790. Adhatoda vasica Ness in } \\
\text { Well. Pl. As. Rar. 3: } 103.1932 .\end{array}$ & Basak & Acanthaceae & $\begin{array}{l}\text { The leaves, barks and young } \\
\text { stems are extensively used as a } \\
\text { remedy for cold, cough, } \\
\text { bronchitis and asthma, } \\
\text { Powdered leaves used for skin } \\
\text { affections. }\end{array}$ & $\begin{array}{l}\text { One cup of leaf extract } \\
\text { together with } 10 \text { gms. Taggery } \\
\text { and 3-4 cloves boiled down to } \\
1 / 2 \text { cup, prescribed for common } \\
\text { cold and cough }\end{array}$ & Common \\
\hline $\begin{array}{l}\text { 3. Aerva lanata (Linn.) Juss. in } \\
\text { Ann. Mus. Nat. Hist. Par } \\
\text { 2:131.1808. Achyranthes } \\
\text { lanata Linn. Sp. PI. 204. } 1753 .\end{array}$ & Chaya, Daya Phul & Amaranthaceae & $\begin{array}{l}\text { The plant is diuretic, used in } \\
\text { lithiasia. The root is demulcent, } \\
\text { diuretic, useful in the treatment } \\
\text { of headache. }\end{array}$ & $\begin{array}{l}\text { One teaspoonful plant juice is } \\
\text { taken with few drops of honey } \\
\text { to check cough and same } \\
\text { without honey taken in empty } \\
\text { stomach to control blood } \\
\text { sugar. }\end{array}$ & Abundant \\
\hline $\begin{array}{l}\text { 4. Ageratum conyzoides Linn. } \\
\text { Sp.PI. } 839.1753\end{array}$ & Uchunti & Asteraceae & $\begin{array}{l}\text { Decoction or infusion of the } \\
\text { plant used in diarrhoea, } \\
\text { dysentery, colic with flatulence } \\
\text { and other gasto-intestinal } \\
\text { ailments. }\end{array}$ & No local use & Abundant \\
\hline $\begin{array}{l}\text { 5. Amaranthus viridis Linn. Sp. PI. } \\
\text { 1405. } 1753\end{array}$ & Notey & Amaranthaceae & $\begin{array}{l}\text { The plant is cooling, digestible, } \\
\text { laxative, diuretic, stomachaic, }\end{array}$ & $\begin{array}{l}\text { The boiled leaves and roots } \\
\text { given to children as a laxative. }\end{array}$ & Abundant \\
\hline
\end{tabular}




\begin{tabular}{|c|c|c|c|c|c|}
\hline & & & $\begin{array}{l}\text { antipyretic, improves the } \\
\text { appetite. }\end{array}$ & & \\
\hline $\begin{array}{l}\text { 6. Amischophacelus axillaris } \\
\text { (Linn.) Rolla Rao and Kamm in } \\
\text { Journ. Linn. Soc. Bat. } \\
\text { 59:306,1966. Commelina } \\
\text { axillaris Linn. Sp. PI. 42. } 1753 \text {. }\end{array}$ & Baganulla Herb & Commelinaceae & Seeds may be used as food. & No local use. & Common \\
\hline $\begin{array}{l}\text { 7. Ammannia baccifera Linn. Sp. } \\
\text { PI. ed. 2. 175. } 1762\end{array}$ & Dadmari & Lythraceae & $\begin{array}{l}\text { The fresh leaves, bruised and } \\
\text { applied to part intended to be } \\
\text { blistered. The leaves are } \\
\text { applied to cure herpetic } \\
\text { eruptions. Herb is reported to } \\
\text { possess anti-typhoid and anti- } \\
\text { tubercular properties. }\end{array}$ & $\begin{array}{l}\text { Leaf juice is externally applied } \\
\text { to relief the rheumatic pain. }\end{array}$ & Abundant \\
\hline $\begin{array}{l}\text { 8. Anagallis arvensis } \\
\text { Linn. Sp. PI. 148, } 1753 .\end{array}$ & Not available & Primulaceae & $\begin{array}{l}\text { Plant used for dropsy, leprosy, } \\
\text { hydrophobia, mania and other } \\
\text { cerebral affections;cures } \\
\text { ophthalmia, inflammations, } \\
\text { sores, pain in liver and kidney. }\end{array}$ & No local use. & Common \\
\hline $\begin{array}{l}\text { 9. Andrographis paniculata } \\
\text { (Burm.f.) Wall ex Ness in wall. } \\
\text { PI. As. Ras. 3:116. } 1832\end{array}$ & Kalmegh & Acanthaceae & $\begin{array}{l}\text { Decoction used for sluggishness } \\
\text { of liver and in jaundice. Leaves } \\
\text { and roots used as a febrifuge, } \\
\text { cholagogue and anthelmintic. }\end{array}$ & $\begin{array}{l}\text { Village people are used to } \\
\text { chew } 3-5 \text { leaves in empty } \\
\text { stomach to prevent liver and } \\
\text { stomach diseases. The } \\
\text { expressed juice of the leaves } \\
\text { together with cardamoms, } \\
\text { cloves, cinnamon etc. is dried } \\
\text { in the Sun and made into little } \\
\text { globules, which are prescribed } \\
\text { for infants to relief griping, }\end{array}$ & Rare \\
\hline
\end{tabular}




\begin{tabular}{|c|c|c|c|c|c|c|}
\hline & & & & & $\begin{array}{l}\text { irregular stools and loss of } \\
\text { appetite. }\end{array}$ & \\
\hline & $\begin{array}{l}\text { Anisbomeles indica } \\
\text { (Linn.) O.Kuntze, Rev. Gen. PI. } \\
\text { 2: 512. 1891. Nepeta indica } \\
\text { Linn. Sp. PI. 571.1753. }\end{array}$ & Gobura & Lamiaceae & $\begin{array}{l}\text { The herb used as an astringent } \\
\text { carminative and tonic. The } \\
\text { essential oil obtained from the } \\
\text { herb is used in uterine } \\
\text { affections. }\end{array}$ & No local use & Common \\
\hline & $\begin{array}{l}\text { Bacopa monnieri } \\
\text { (Linn.) nettstein in Engl. \& } \\
\text { Prant. Pflanzenfam. 4(36): } \\
77.1891 \text { (monniera). }\end{array}$ & Brahni, Brihmisak & Scrophulariaceae & $\begin{array}{l}\text { The herb used for epilepsy, } \\
\text { insanity and other nervous } \\
\text { diseases. }\end{array}$ & $\begin{array}{l}\text { The herb fried with 'ghee' and } \\
\text { taken to improve intellect by } \\
\text { the villagers. }\end{array}$ & Abundant \\
\hline & $\begin{array}{l}\text { Biophytum sensitivum (Linn.) } \\
\text { DC. Prod. 1:690 1824.Oxalis } \\
\text { sensitive Linn. Sp. PI. } \\
434.1753 .\end{array}$ & $\begin{array}{l}\text { Jhalai, } \\
\text { Bannaranga }\end{array}$ & Oxalidaceae & $\begin{array}{l}\text { Plant ash is mixed with lime } \\
\text { juice and given for } \\
\text { stomachache. Decoction of } \\
\text { leaves given for diabetes and } \\
\text { asthma. }\end{array}$ & $\begin{array}{l}\text { Plant juice rubbed to cure } \\
\text { muscle cramps and } \\
\text { inflammatory tumours. }\end{array}$ & Common \\
\hline 13. & $\begin{array}{l}\text { Boerhaavia diffusa Linn. Sp. PI. } \\
\text { 3. } 1753\end{array}$ & Punarnava & Nyctaginaceae & $\begin{array}{l}\text { Roots considered expectorant, } \\
\text { diurectic and laxiative, used in } \\
\text { asthma. Mixed with dried ginger } \\
\text { it is given in utricaria. }\end{array}$ & $\begin{array}{l}\text { Half-tea spoonful leaf juice is } \\
\text { given to cure Jaundice. }\end{array}$ & Common \\
\hline 14. & $\begin{array}{l}\text { Brassica nigra (Linn.) Koch in } \\
\text { Rohling's Deutschl. Fl. ed. 3. IV } \\
\text { (1833) } 713 \text { et Syn. ed. 1(1835) } \\
\text { 59. Sinapis nigra Linn. Sp. PI. } \\
\text { ed. } 1 \text { II. 668. } 1753 .\end{array}$ & Kalasarisha & Brassicaccae & $\begin{array}{l}\text { Seeds are given with warm } \\
\text { water as emetic in narcotic } \\
\text { poisoning and edible as cooking } \\
\text { oil, which is extracted from the } \\
\text { seed. }\end{array}$ & $\begin{array}{l}\text { Warm seed oil rubbed in the } \\
\text { chest and back during cough } \\
\text { and cold specially for children. }\end{array}$ & Abundant \\
\hline 15. & $\begin{array}{l}\text { Cajanus cajan (Linn.) Millsp. } \\
\text { Field. Columb. Mus. Bot. 2:53. } \\
\text { 1900. Cytisus cajan Linn. Sp. } \\
\text { PI. 739. } 1753 .\end{array}$ & Arhar & Fabaceae & $\begin{array}{l}\text { The seed is acrid, astringent to } \\
\text { the bowels, anthelmintic, } \\
\text { restores lost taste, cure leprosy, } \\
\text { ulcers of mouth, tumours, } \\
\text { bronchitis, vomiting, heat }\end{array}$ & $\begin{array}{l}\text { Leaf juice } 1 / 2 \text { cup once daily in } \\
\text { empty stomach is prescribed } \\
\text { for jaundice }\end{array}$ & Abundant \\
\hline
\end{tabular}




\begin{tabular}{|c|c|c|c|c|c|}
\hline & & & $\begin{array}{l}\text { diseases, piles, cough, } \\
\text { biliousness (Ayurveda). }\end{array}$ & & \\
\hline $\begin{array}{l}\text { 16. Canscora diffusa (Vahl.) R. Br. } \\
\text { ex Roem. \& Schult. Syst. Veg. } \\
\text { 3:301. } 1820 \text {. Gentiana diffusa } \\
\text { Vahl. Symb. Bot. } 3: 47,1794 \text {. }\end{array}$ & Dankuni & Gentianaceae & $\begin{array}{l}\text { Fresh juice of the plant } \\
\text { prescribed in insanity, epilepsy } \\
\text { and nervous debility. }\end{array}$ & No local use. & Common \\
\hline $\begin{array}{l}\text { 17. Cardiospermum halicacabum } \\
\text { Linn. Sp.PI. } 366.1753 .\end{array}$ & $\begin{array}{l}\text { Lataphatkari, } \\
\text { sibjhul }\end{array}$ & Sapindaceae & $\begin{array}{l}\text { Roots used for rheumatism, } \\
\text { lumbago, nervous diseases. } \\
\text { Leaves used as poultice in } \\
\text { rheumatism. }\end{array}$ & No local use. & Common \\
\hline $\begin{array}{l}\text { 18. Catharanthus roseus (Linn.) G. } \\
\text { Don, Gen. Syst. 4:95. } 1838 . \\
\text { Vinca rosea Linn. Syst. Nat. ed. } \\
\text { 10.944.1759 }\end{array}$ & Nayantara & Apocynaceae & $\begin{array}{l}\text { The alkaloids of the roots } \\
\text { possess hypotensive, sedative } \\
\text { and tranquillizing properties. }\end{array}$ & $\begin{array}{l}\text { Fresh leaves (1-2) are chewed } \\
\text { in empty stomach to check } \\
\text { blood sugar. }\end{array}$ & Abundant \\
\hline $\begin{array}{l}\text { 19. Chenopodium ambrosiodes } \\
\text { Linn. Sp. PI. } 219.1783 .\end{array}$ & $\begin{array}{l}\text { Bethusag, Candan } \\
\text { betu. }\end{array}$ & Chenopodiaceae & $\begin{array}{l}\text { An infusion of herb is } \\
\text { carminative and diaphoretic. }\end{array}$ & $\begin{array}{l}\text { Juice of the herb used as an } \\
\text { antibiotic against many forms } \\
\text { of internal parasites including } \\
\text { round worms, hooke worms } \\
\text { and intestinal amoebae. }\end{array}$ & Common \\
\hline $\begin{array}{l}\text { 20. Clerodendrum viscosum Vent. } \\
\text { Jard. Malm. T. 25. } 1803 .\end{array}$ & Bhant, Ghentu & Verbenaceae & $\begin{array}{l}\text { Paste of the roots and leaves } \\
\text { are employed externally for } \\
\text { treatment of tumours and skin } \\
\text { diseases. }\end{array}$ & $\begin{array}{l}\text { Root juice is used as } \\
\text { anthelmintic specially for the } \\
\text { children. }\end{array}$ & Abundant \\
\hline $\begin{array}{l}\text { 21. Commelina diffusa Burm. f. Fl. } \\
\text { end. } 18 \text {, t. 7.f. 2. } 1768\end{array}$ & Not available & Commelinaceae & $\begin{array}{l}\text { Bruised plant applied to boils, } \\
\text { itches and burns. Leaves used } \\
\text { for poulticing sores. }\end{array}$ & No local use & Abundant \\
\hline $\begin{array}{l}\text { 22. Corchorus aestuans Linn. Sp. } \\
\text { PI. } 715.1753 .\end{array}$ & Titapat & Tiliaceae & Seeds used in stomachache. & No local use & Occasional \\
\hline
\end{tabular}




\begin{tabular}{|c|c|c|c|c|c|c|}
\hline & $\begin{array}{l}\text { Crotalaria verrucosa Linn. Sp. } \\
\text { PI. 715. } 1753 .\end{array}$ & Basan, Jhanjhana & Fabaceae & $\begin{array}{l}\text { Leaves cure biliousness, } \\
\text { dyspepsia, fever, blood } \\
\text { impurities, heart complaints, } \\
\text { throat and mouth diseases. }\end{array}$ & No local use & Rare \\
\hline 24. & $\begin{array}{l}\text { Cuscuta chinensis Lam. Encycl. } \\
\text { Method. II. 229. } 1786 .\end{array}$ & Swarnalata & Cuscutaceae & $\begin{array}{l}\text { Crushed seeds are used as } \\
\text { purgative. }\end{array}$ & $\begin{array}{l}\text { Crushed herb is applied } \\
\text { externally against the skin } \\
\text { itching. }\end{array}$ & Abundant \\
\hline 25. & $\begin{array}{l}\text { Derris indica (Lam.) Bennet in } \\
\text { J. Bomb. Nat. Hist. SOC. } \\
\text { 68:302. } 1971\end{array}$ & Karonj, Karanja & Fabaceae & $\begin{array}{l}\text { Root, bark, leaf and fruits are } \\
\text { anthelmintic. Commonly bark is } \\
\text { crushed with water ( } 10 \text { gms } \\
\text { bark in } 1 \text { cup water) and given } \\
\text { one teaspoonful with slight } \\
\text { sugar twice daily to expel the } \\
\text { worm. Leaves are digestive, } \\
\text { laxative and anthelmentic and } \\
\text { the juice is preserved in } \\
\text { dyspepsia, leprosy and } \\
\text { gonorrhoea. }\end{array}$ & No local use. & Rare \\
\hline 26. & $\begin{array}{l}\text { Duranta repens Linn. Sp. PI. } \\
637.1753 .\end{array}$ & Duranto & Verbenaceae & $\begin{array}{l}\text { Fruits contain an alkaloid } \\
\text { analogus to narcotine. } \\
\text { Mecerated fruits yield a juice } \\
\text { which even in dilutions of } 1: 100 \\
\text { parts of water is lethal to } \\
\text { mosquito larvae. }\end{array}$ & No local use. & Abundant \\
\hline 27. & $\begin{array}{l}\text { Flacourtia indica (Burm.f.) } \\
\text { Merrill, Interpr. Rumph. Herb. } \\
\text { Amb. 377. 1917. Gmelina } \\
\text { indica Burm. f. Fl. Ind. 132.t. } \\
\text { 39. f., 5.1768. }\end{array}$ & $\begin{array}{l}\text { Bencli, Baichi, } \\
\text { Birja, Katai. }\end{array}$ & Flacourtiaceae & $\begin{array}{l}\text { Fruit used in jaundice and } \\
\text { enlarged spleen. Bark is } \\
\text { astringent and diuretic. }\end{array}$ & No local use. & Common \\
\hline
\end{tabular}




\begin{tabular}{|c|c|c|c|c|c|}
\hline $\begin{array}{l}\text { 28. Heliopropium indicum Linn. } \\
\text { Sp. PI. } 130.1753 .\end{array}$ & Hatisur & Boraginaceae & $\begin{array}{l}\text { Decoction of leaf used in fever; } \\
\text { Root juice used in cough and } \\
\text { fever. }\end{array}$ & $\begin{array}{l}\text { Plant extract commonly used } \\
\text { for skin diseases, wounds and } \\
\text { ulcers. }\end{array}$ & Common \\
\hline $\begin{array}{l}\text { 29. Hemidesmus indicus (Linn.) R. } \\
\text { Br. In Aiton, Hort. Kew. ed. 2, } \\
\text { 2:75. 1811. Periploca indica } \\
\text { Linn. Sp. Pl. 211.1753. }\end{array}$ & Auantamul & Periplocaceae & $\begin{array}{l}\text { Dried roots used in } \\
\text { rheumatism, gravel and other } \\
\text { urinary diseases and skin } \\
\text { troubles. }\end{array}$ & $\begin{array}{l}\text { Root juice is taken for } \\
\text { dysentery (one tea spoonful } \\
\text { with sugar in empty stomach.) }\end{array}$ & Rare \\
\hline $\begin{array}{l}\text { 30. Hygrophila auriculata } \\
\text { (Schum.) Heine, kew Bull. 16: } \\
\text { 172, 1962. Barleria auriculata } \\
\text { Schum. in Schum. \& thorn. } \\
\text { Beskr. Guin. P: } 285.1827 \text {. }\end{array}$ & Kulekhara & Acanthaceae & $\begin{array}{l}\text { Leaves useful in diarrhea, } \\
\text { dysentery, urinary discharges, } \\
\text { inflammations, biliousness, } \\
\text { diseases of eye, anaemia, } \\
\text { constipation. }\end{array}$ & $\begin{array}{l}\text { The seeds are given for } \\
\text { gonorrhoea. Tender shoot and } \\
\text { leaf juice, } 1 / 2 \text { cup twice daily is } \\
\text { prescribed in severe anaemia. }\end{array}$ & Abundant \\
\hline $\begin{array}{l}\text { 31. Hygrophila phlomoides Ness in } \\
\text { Wall. Pl. As. Ras. } 3.80 .1832 \text {. }\end{array}$ & Not available & Acanthaceae & $\begin{array}{l}\text { Leaves used in poultices for } \\
\text { boils. }\end{array}$ & No local use. & Rare \\
\hline $\begin{array}{l}\text { 32. Hydrolea zeylanica (Linn.) } \\
\text { Vahl. Symb. Bat. 2:46.1791. } \\
\text { Nama zeylanica Linn. Sp. PI. } \\
226.1753 .\end{array}$ & Isha-Langulia & $\begin{array}{l}\text { Hydrophylla- } \\
\text { ceae }\end{array}$ & Leaves are used as antiseptic. & $\begin{array}{l}\text { Leaves applied in form of } \\
\text { poultices on neglected } \\
\text { external wounds. }\end{array}$ & Occasional \\
\hline $\begin{array}{l}\text { 33. Ipomoca aquitica Forsk. Fl. } \\
\text { Aeg. Arab. } 44.1775 \text {. }\end{array}$ & Kalmi & Convolvulaceae & $\begin{array}{l}\text { Roots eaten in times of scarcity. } \\
\text { Juice used as an emetic in cases } \\
\text { of opium and arsenial } \\
\text { poisoning. }\end{array}$ & Leaves are eaten as pot herbs. & Abundant \\
\hline $\begin{array}{l}\text { 34. Justicia gendarussa Burm. F. } \\
\text { Fl. ind. 10. } 1768 .\end{array}$ & Jagat madan & Acanthaceae & $\begin{array}{l}\text { Plant useful in bronchitis, } \\
\text { inflammations, vaginal } \\
\text { discharges, eye diseases and } \\
\text { fever. }\end{array}$ & $\begin{array}{l}\text { Leaves and tender shoots are } \\
\text { diaphoretic and given in } \\
\text { chronic rheumatism in the } \\
\text { form of decoction by local } \\
\text { people. Crushed leaf applied } \\
\text { locally in eczema. The juice of } \\
\text { the fresh leaf dropped into the } \\
\text { ear for earache. }\end{array}$ & Common \\
\hline
\end{tabular}


ISSN: 2230-7605 (Online); ISSN: 2321-3272 (Print)

Int J Pharm Biol Sci.

\begin{tabular}{|c|c|c|c|c|c|c|}
\hline & $\begin{array}{l}\text { Kleinhovia hospita Linn. Sp. PI. } \\
\text { Ed. 2. 1365, } 1753 .\end{array}$ & Bola & Strculiaceae & Leaf juice used as an eye-wash. & $\begin{array}{l}\text { Decoction of leaves prescribed } \\
\text { for scabies and skin eruptions. }\end{array}$ & Rare \\
\hline 36. & $\begin{array}{l}\text { Leonurus sibricus Linn. Sp. PI. } \\
\text { 584. } 1753 .\end{array}$ & Raktadrone & Lamiaceae & $\begin{array}{l}\text { Leaves and roots febrifuge. Leaf } \\
\text { extract effective for uterus } \\
\text { contraction. }\end{array}$ & $\begin{array}{l}\text { Root extract is given to use } \\
\text { menstrual disorder. }\end{array}$ & Abundant \\
\hline 37. & $\begin{array}{l}\text { Leucas lavendulaefolia J.E. } \\
\text { Smith in Ress. Cyclop. 20:n. } 2 . \\
\text { 1819. L. linifolia (Roth) spreng. } \\
\text { Syst. 2: } 743.1825 .\end{array}$ & $\begin{array}{l}\text { Sweatadrone, } \\
\text { Halkasa }\end{array}$ & Lamiaceae & $\begin{array}{l}\text { Leaves are useful in piles and } \\
\text { sore eyes. Decoction of leaves } \\
\text { used as a sedative, stomachic } \\
\text { and vermifuge. Poultice of fresh } \\
\text { leaves applied to old sores and } \\
\text { dermatosis. }\end{array}$ & $\begin{array}{l}\text { Leaf juice is mixed with honey } \\
\text { (few drops) and used in fever } \\
\text { for children. }\end{array}$ & Abundant \\
\hline 38. & $\begin{array}{l}\text { Lippia javanica } \\
\text { (Burm.f.)Spreng.Syst. 2: } 752 . \\
\text { 1825. Verbena javanica Burm. } \\
\text { f. FI. Ind. 12:t. 6, f. 2. } 1768 . \\
\text { Lippia geminate H.B.K. } \\
\text { Nov.Gen.et. Sp.2:266. } 1818 .\end{array}$ & Not available & Verbenaceae & $\begin{array}{l}\text { Leaves used in stomachache } \\
\text { and nervous diseases. }\end{array}$ & No local use. & Occasional \\
\hline & $\begin{array}{l}\text { Ludwigia adscendens (Linn.) } \\
\text { Hara in J. Jap. Bat. 28:290. } \\
\text { 1953. Jussiaea adscendens } \\
\text { Linn. Mant. PI. 1:69.1767. J. } \\
\text { repens Linn. Sp. PI. 388. } 1753 \\
\text { (non-Iudwigia repens Forst } \\
\text { 1771). }\end{array}$ & Kesara-dam & Onagraceac & $\begin{array}{l}\text { Plant is used for ulcers and skin } \\
\text { complaints. }\end{array}$ & No local use. & Common \\
\hline & $\begin{array}{l}\text { Ludwigia perennis Linn. Sp. Pl. } \\
\text { 519. } 1753 .\end{array}$ & Bonlong & Onagsaceac & $\begin{array}{l}\text { Plant is boiled in oil which is } \\
\text { applied to the body externally } \\
\text { to bring down fever. }\end{array}$ & No local use. & Abundant \\
\hline & $\begin{array}{l}\text { Mimosa pudica Linn. Sp. PI. } \\
\text { 518.1753. }\end{array}$ & Lajjabati & Mimosaceae & $\begin{array}{l}\text { Decoction of root together with } \\
\text { few drops of honey is } \\
\text { prescribed for acute belly pain } \\
\text { and also for gravel. }\end{array}$ & No local use. & Common \\
\hline
\end{tabular}




\begin{tabular}{|c|c|c|c|c|c|c|}
\hline & $\begin{array}{l}\text { Monochoria hastata (Linn.) } \\
\text { Solans in DC. Mon. Phan. } \\
\text { 4:523.1883. Pontederia } \\
\text { hastata Linn. Sp. Pl. 288. } 1753 .\end{array}$ & Not available & Pontederiaceae & $\begin{array}{l}\text { Juice of the leaves applied to } \\
\text { boils. Rhizomes are pounded } \\
\text { with charcoal and used for } \\
\text { scurf. }\end{array}$ & No local use. & Abundant \\
\hline 43. & $\begin{array}{l}\text { Oxalis corniculata Linn. Sp. PI. } \\
435.1753 .\end{array}$ & Amrul & Oxalidaceae & $\begin{array}{l}\text { In slight forms of chronic } \\
\text { dysentery the leaves boiled in } \\
\text { milk and given twice or thrice a } \\
\text { day prove very useful; cure } \\
\text { scurving. }\end{array}$ & $\begin{array}{l}\text { Juice of the leaves is } \\
\text { commonly used to check sore } \\
\text { lips and also to cure skin } \\
\text { disease, dysentery and } \\
\text { diarrhoea. }\end{array}$ & Abundant \\
\hline 44 & $\begin{array}{l}\text { Pedilanthus tithymaloides } \\
\text { (Linn.) Poit. Ann. Mus. Hist. } \\
\text { Nat. par. 19:390. t. 19, } 1812 . \\
\text { Euphorbia tithymaloides Linn. } \\
\text { Sp. PI. } 453.1753 .\end{array}$ & $\begin{array}{l}\text { Belati-sij, } \\
\text { Rangchita }\end{array}$ & Euphorbiaceae & Root powerful emetic. & $\begin{array}{l}\text { Latex of root applied to } \\
\text { leucoderma patches. }\end{array}$ & Abundant \\
\hline 45 & $\begin{array}{l}\text { Phyllanthus fraternus } \\
\text { Webster. Contrib.. Gray Herb. } \\
\text { 176:53. } 1955 .\end{array}$ & Bhui amla & Enphorbianceac & $\begin{array}{l}\text { Fresh roots given in jaundice } \\
\text { and also used as a } \\
\text { galactagogue. Latex applied to } \\
\text { sores. Used for stomach } \\
\text { troubles such as diarrhoea, } \\
\text { dysentery, dyspepsia and colic. }\end{array}$ & No local use. & Abundant \\
\hline 46 & $\begin{array}{l}\text { Physalis minima Linn. Sp. PI. } \\
\text { 183. } 1753 .\end{array}$ & $\begin{array}{l}\text { Bantepariya, } \\
\text { Bontepari }\end{array}$ & Solanaceae & $\begin{array}{l}\text { Fruit considered as tonic, } \\
\text { diuretic and purgative. }\end{array}$ & $\begin{array}{l}\text { Leaf juice together with } \\
\text { mustard oil dropped into the } \\
\text { ear to check earache. }\end{array}$ & Abundant \\
\hline 47. & $\begin{array}{l}\text { Pithecellobium dulce (Roxb.) } \\
\text { Benth. in Hook, Long. Journ. } \\
\text { Bot. } 3 \text { : 199. 1844. Mimosa } \\
\text { dulcis Roxb. PI. Cor. 1:67: t.99. } \\
\text { 1795. Inga dulcis (Roxb.) Willd. } \\
\text { Sp. PI. 4:1105. 1806. }\end{array}$ & Dekhani babul & Mimosaceae & Bark is used as a febrifuge. & $\begin{array}{l}\text { Bark soaked in water for } \\
\text { several hours and the water is } \\
\text { taken as a remedy of fever. }\end{array}$ & Common \\
\hline & $\begin{array}{l}\text { Polygonum barbatum Linn. Sp. } \\
\text { PI. 362. } 1753 .\end{array}$ & Bekh-unjubaz & Polygonaceae & $\begin{array}{l}\text { Decoction of leaves and shoots } \\
\text { used as a remedy for ulcer. }\end{array}$ & No local use. & Occasional \\
\hline
\end{tabular}




\begin{tabular}{|c|c|c|c|c|c|c|}
\hline & $\begin{array}{l}\text { Psidium guajava Linn. Sp. Pl. } \\
\text { 470. } 1753 .\end{array}$ & Peyasa & Myrtaceae & $\begin{array}{l}\text { Leaves used as astringent for } \\
\text { bowel troubles. Decoction of } \\
\text { bark given in diarrhoea. }\end{array}$ & $\begin{array}{l}\text { Tender leaves often chewed } \\
\text { with salt to check gum } \\
\text { bleeding and other tooth } \\
\text { troubles. }\end{array}$ & $\begin{array}{l}\text { Not very common } \\
\text { in the studied } \\
\text { area but } \\
\text { commonly } \\
\text { planted in the } \\
\text { other area of the } \\
\text { district. }\end{array}$ \\
\hline & $\begin{array}{l}\text { Rumex vesicarius Linn. Sp. PI. } \\
\text { 336. } 1753 .\end{array}$ & $\begin{array}{l}\text { Chak, chuk, } \\
\text { chuka, } \\
\text { Chukapalang. }\end{array}$ & Polygonance & $\begin{array}{l}\text { The herb is useful in heart } \\
\text { troubles, pain, tumours, } \\
\text { alcoholism, bronchitis, piles, } \\
\text { vomiting. Leaves cooling, } \\
\text { diuretic. Roasted seeds used in } \\
\text { dysentery. }\end{array}$ & No local use. & Abundant \\
\hline . & $\begin{array}{l}\text { Rungia pectinata (Linn.) Ness } \\
\text { in DC Prods. 11:469. } 1847 . \\
\text { Justicia pectinata Linn. } \\
\text { Amoen. Aced. 4:299.1759. } \\
\text { Rungia parviflora (Retz.) Ness } \\
\text { Var. pectinata (Linn.) C.B. } \\
\text { Clarke in FBI 4:550.1885. }\end{array}$ & Pindi & Acanthaceae & $\begin{array}{l}\text { Fresh leaf juice prescribed for } \\
\text { the children suffering from } \\
\text { small-pox, one tablespoonful } \\
\text { twice daily. }\end{array}$ & $\begin{array}{l}\text { Few drops of root extract } \\
\text { together with honey is } \\
\text { prescribed for fever, especially } \\
\text { for children; }\end{array}$ & Abundant \\
\hline 52. & $\begin{array}{l}\text { Sida cordata (Burm.f.) Borss., } \\
\text { Blumea 14:182. } 1966 . \\
\text { Melochia cordata Burm. f. FI. } \\
\text { Ind. } 1768 .\end{array}$ & Besela, Junka & Malvaceae & $\begin{array}{l}\text { Leaves applied to cuts and } \\
\text { bruises }\end{array}$ & $\begin{array}{l}\text { Leaf juice is given to the } \\
\text { pregnant women when they } \\
\text { suffer from diarrhoea. }\end{array}$ & Common \\
\hline 53. & $\begin{array}{l}\text { Sida rlombifola Linn. Sp. PI. } \\
\text { 684. } 1753 .\end{array}$ & Lalberela & Malvaceae & $\begin{array}{l}\text { Leaf Juice used in rheumatism } \\
\text { and tuberculosis. Roots and } \\
\text { leaves contain ephedrine. }\end{array}$ & $\begin{array}{l}\text { An infusion of root is given in } \\
\text { dysentery. }\end{array}$ & Abundant \\
\hline 54. & $\begin{array}{l}\text { Smilax glabra Roxb. FI. Ind. III. } \\
792.1832 .\end{array}$ & $\begin{array}{l}\text { Harina-shulke- } \\
\text { china. }\end{array}$ & Smilacaceae & $\begin{array}{l}\text { Decoction of wood used for } \\
\text { venereal diseases. }\end{array}$ & $\begin{array}{l}\text { A decoction of fresh root used } \\
\text { to cure sores and venereal } \\
\text { complaints. }\end{array}$ & Rare \\
\hline
\end{tabular}




\begin{tabular}{|c|c|c|c|c|c|}
\hline $\begin{array}{l}\text { 55. Smilax prolifera Roxb. Fl. Ind. } \\
\text { II.795, } 1832 \text {. }\end{array}$ & Not available & Smilacaceae & $\begin{array}{l}\text { Roots ground with old molasses } \\
\text { or with coagulated cow's milk, } \\
\text { is mixed with water and drink } \\
\text { as a remedy against blood- } \\
\text { mixed stools in dysentery and } \\
\text { against 'aradaud', a urinary } \\
\text { complaint in which the urine is } \\
\text { dark and reddish. }\end{array}$ & $\begin{array}{l}\text { Commonly the root is used for } \\
\text { urinal diseases. }\end{array}$ & Rare \\
\hline $\begin{array}{l}\text { 56. Solanum indicum Linn. Sp. PI. } \\
187.1753 .\end{array}$ & $\begin{array}{l}\text { Byakura, } \\
\text { gurkamai }\end{array}$ & Solanaceae & $\begin{array}{l}\text { Fruits laxative and digestive. } \\
\text { Roots useful in cough and } \\
\text { catarrhal affections. }\end{array}$ & $\begin{array}{l}\text { Leaves and fruits rubbed up } \\
\text { with sugar and used as an } \\
\text { external application to itch. }\end{array}$ & Occasional \\
\hline $\begin{array}{l}\text { 57. Solanum nigram Linn. Sp. PI. } \\
186,1753 .\end{array}$ & $\begin{array}{l}\text { Gurkamai, } \\
\text { Kakmachi }\end{array}$ & Solanaceae & $\begin{array}{l}\text { Herb used as diuretic and } \\
\text { laxative. Leaves used as an } \\
\text { adulterant of belladona. }\end{array}$ & $\begin{array}{l}\text { Leaves and tender shoots are } \\
\text { boiled and eaten like spinach. } \\
\text { Freshly prepared extract of } \\
\text { herb is used as a remedy of } \\
\text { cirrhosis of liver. }\end{array}$ & Abundant \\
\hline $\begin{array}{l}\text { 58. Sonchus arvensis Linn. Sp. PI. } \\
793,1753 .\end{array}$ & Banpalang & Asteraceeae & $\begin{array}{l}\text { Juice of roots used in cough, } \\
\text { bronchitis and asthma. }\end{array}$ & $\begin{array}{l}\text { Latex from root often used to } \\
\text { cure eye irritation. }\end{array}$ & Common \\
\hline $\begin{array}{l}\text { 59. Spermacoce articularis Linn. f. } \\
\text { Suppl. PI. 119. } 1782 \text {. }\end{array}$ & $\begin{array}{l}\text { Madana- } \\
\text { banta-kadu }\end{array}$ & Rubiaceae & $\begin{array}{l}\text { The seeds are crushed and } \\
\text { mixed with leaf juice of } \\
\text { Andrographis paniculata and } \\
\text { used against dysentery. }\end{array}$ & $\begin{array}{l}\text { The vapour of the herbs is } \\
\text { inhaled to kill the tooth } \\
\text { worms. }\end{array}$ & Common \\
\hline $\begin{array}{l}\text { 60. Spilanthes paniculata Wall. ex } \\
\text { De. Prodr. 5:625.1836 }\end{array}$ & Marhati tiga & Asteraccae & $\begin{array}{l}\text { Decoction of herb used in } \\
\text { scabies and psoriasis. }\end{array}$ & $\begin{array}{l}\text { Pungent flowers chewed to } \\
\text { relief in throat affections and } \\
\text { paralysis of tongue. Also, used } \\
\text { for stammering in children. }\end{array}$ & Abundant \\
\hline $\begin{array}{l}\text { 61. Stephania japonica (Thunb.) } \\
\text { Miers., Ann. Ma. Nat. Hist. Ser. } \\
\text { 3, 18:14.1866. Menispema } \\
\text { japonicum Thunb., Fl. Jap. } \\
\text { 193-1784. }\end{array}$ & $\begin{array}{l}\text { Agandnemuka, } \\
\text { Akanadi, Nimuka. }\end{array}$ & Menispermaceae & $\begin{array}{l}\text { Bitter root used in many } \\
\text { Ayurvedic preparations. }\end{array}$ & $\begin{array}{l}\text { Few drops of decoction of root } \\
\text { with a cup of water is } \\
\text { prescribed in fever for children } \\
\text { and also used in urinary } \\
\text { troubles. }\end{array}$ & Rare \\
\hline
\end{tabular}




\begin{tabular}{|c|c|c|c|c|c|c|}
\hline & $\begin{array}{l}\text { Streblus asper Lour. Fl. } \\
\text { Cochinch. 2:615.1790. }\end{array}$ & Sheora & Moraceae & $\begin{array}{l}\text { Bark extract is prescribed for } \\
\text { diarrhoea and dysentery. Seeds } \\
\text { used in piles and diarrhoea. } \\
\text { Externally the paste applied in } \\
\text { leucoderma. }\end{array}$ & Root extract is given in ulcers. & Common \\
\hline & $\begin{array}{l}\text { Terminalia arjuna (Roxb.) Wt. } \\
\text { \& Arn. Prodr. } 314.1834 . \\
\text { Pentaptera arjuna Roxb. FI. } \\
\text { Ind. 2:438. } 1824 .\end{array}$ & Arjun & Combretaccae & $\begin{array}{l}\text { The bark is antidysentric, } \\
\text { diuretic, gives relief in } \\
\text { symptomatic hypertension. }\end{array}$ & $\begin{array}{l}\text { Dried bark powder eaten with } \\
\text { rice in lunch to check the high } \\
\text { blood pressure. Bark extract is } \\
\text { used for tooth-ache. }\end{array}$ & Rare \\
\hline & $\begin{array}{l}\text { Tridax procumbens Linn. Sp. } \\
\text { PI. 900. } 1753 .\end{array}$ & Tridakshya & Asteraceae & $\begin{array}{l}\text { Leaf juice mixed with equal } \\
\text { volume of the juice of Centella } \\
\text { asiatica and taken twice daily } \\
\text { (teaspoonful) for diarrhea. }\end{array}$ & $\begin{array}{l}\text { Leaf juice given for the } \\
\text { treatment of dysentery and } \\
\text { diarrhoea. }\end{array}$ & Abundant. \\
\hline 65. & $\begin{array}{l}\text { Vernonia cinerea (Linn.) Less } \\
\text { in Linnaea } 4: 291.1829 . \\
\text { Conyza cinerea Linn. Sp. PI. } \\
862.1753 .\end{array}$ & $\begin{array}{l}\text { Kukursonka, } \\
\text { Kukshim. }\end{array}$ & Asteraceae & $\begin{array}{l}\text { Plant possesses strong } \\
\text { diaphoretic properties and used } \\
\text { to produce perspiration in } \\
\text { fever. }\end{array}$ & $\begin{array}{l}\text { Plant juice commonly used to } \\
\text { cure asthma. }\end{array}$ & Abundant. \\
\hline
\end{tabular}


The above mentioned 65 plants may be categorized in the following way:

Table II: Different Parts of Plants Used for Medicinal Purposes

\begin{tabular}{ll}
\hline Name of the Parts & Number of Plants \\
\hline Whole Plant & 22 \\
Leaf & 35 \\
Roots and Rhizomes & 23 \\
Stem and Bark & 11 \\
Flowers & 01 \\
Fruits & 05 \\
Seeds & 10 \\
\hline
\end{tabular}

It is evident from the field survey that out of 65 plants, most of the cases leaves (35) are used followed by roots and rhizomes (23), whole plant (22), stem and bark (11), seeds (10) and fruits are used only in five cases. Only one case flowers are used.

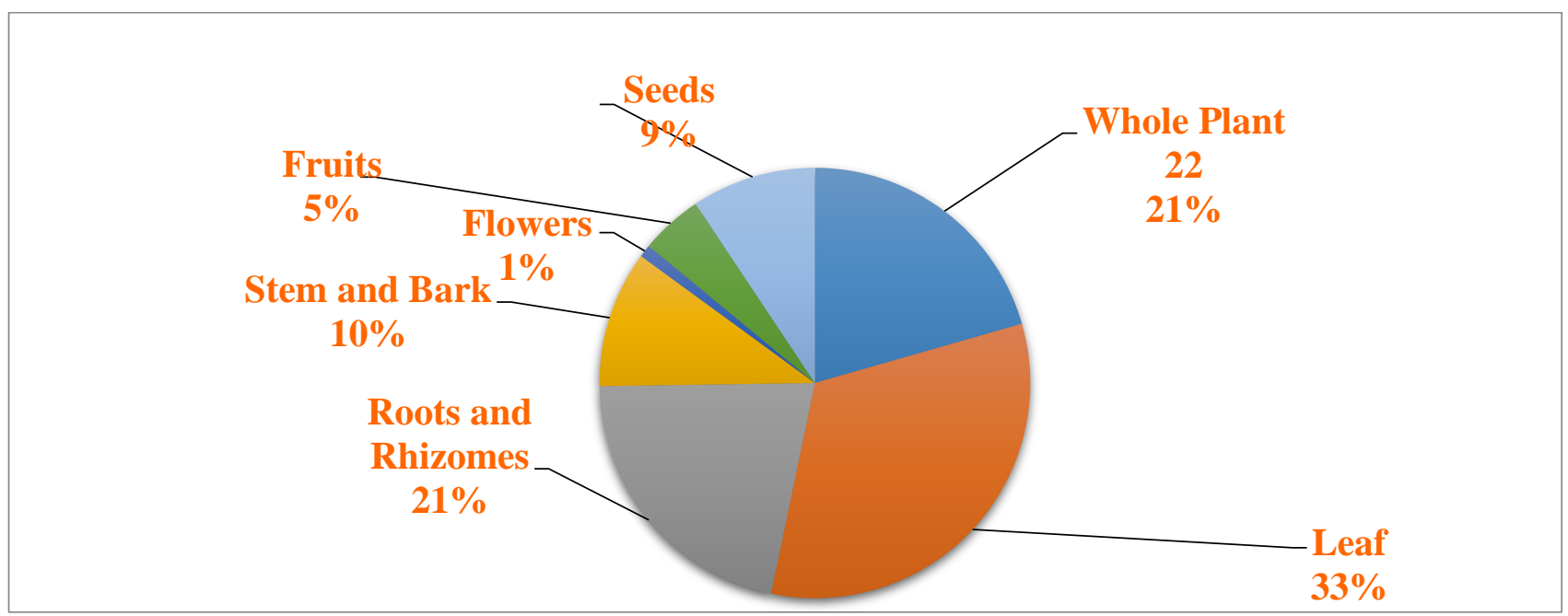

Figure I: Different Parts of Plants Used for Medicinal Purposes

Maximum percentage of leafy parts is used for medicinal purposes and minimum percentage of flower is used for this purposes.

Table III: Plants used in different Diseases

\begin{tabular}{ll}
\hline Name of the Disease / Affected Organ & Number of Plants \\
\hline Stomach Trouble & 08 \\
Liver Trouble & 01 \\
Renal Problem & 01 \\
Nervous Problem & 03 \\
Heart Problem & 04 \\
Anaemia & 01 \\
Rheumatism & 01 \\
Uterine Trouble & 05 \\
Jaundice & 01 \\
Cold, Cough, Fever \& Asthma & 10 \\
Constipation & 02 \\
Skin Diseases & 13 \\
Liver Trouble & 01 \\
Eye Problem & 03 \\
Ear Problem & 02 \\
Tooth Problem & 02 \\
Tongue \& Throat Problem & 01 \\
Various Types of Diseases & 15 \\
\hline
\end{tabular}


This work suggests that maximum number of plants (13) are used for dermal diseases. Next prevalent diseases are cold, cough, fever and asthma etc which are treated by 10 plant species and the next prevalent disease is stomach trouble, can be cured by eight different plant species. Other diseases can be prevented by one to four number of plant species.

Table IV: Number of plants distributed in different Families.

\begin{tabular}{ll}
\hline Name of the Family & Number of Plants \\
\hline Amaranthaceae & 03 \\
Acanthaceae & 06 \\
Asteraceae & 05 \\
Commelinaceae & 02 \\
Lythraceae & 01 \\
Primulaceae & 01 \\
Lamiaceae & 03 \\
Scrophulariaceae & 01 \\
Oxalidaceae & 02 \\
Nyctaginaceae & 01 \\
Brassicaceae & 01 \\
Fabaceae & 03 \\
Gentianaceae & 01 \\
Sapindaceae & 01 \\
Apocynaceae & 01 \\
Chenopodiaceae & 01 \\
Verbenaceae & 03 \\
Tiliaceae & 01 \\
Cuscutaceae & 01 \\
Flacourtiaceae & 01 \\
Boraginaceae & 01 \\
Periplocaceae & 01 \\
Hydrophyllaceae & 01 \\
Convolvulaceae & 01 \\
Sterculiaceae & 01 \\
Onagraceae & 02 \\
Mimosaceae & 02 \\
Pontederiaceae & 01 \\
Euphorbiaceae & 02 \\
Solanaceae & 03 \\
Polygonaceae & 02 \\
Myrtaceae & 01 \\
Malvaceae & 02 \\
Smilacaceae & 02 \\
Rubiaceae & 01 \\
Menispermaceae & 01 \\
Moraceae & 01 \\
\hline
\end{tabular}

Surveyed 65 angiospermic plants are distributed in 38 families. Heights number of plants (6) are recorded from Acanthaceae, followed by Asteraceae with 5 plants and 5 families, Amaranthaceae, Lamiaceae, Fabaceae, Verbenaceae and Solanaceae, each of them has 3 plants species. Remaining 8 families with 2 plants each and 23 families with 1 plant each are used to treat the diseases by the people of North 24 Parganas district of West Bengal.

\section{Discussion and Conclusion:}

The information collected by interviewing the local medicinal men need clinical study for confirmation whether they are effective or not and conserve them 
scientifically in their original habitat. At the same time the rare plants like-Andrographis paniculata, Crotalaria verrucosa, Derris indica, Hemidesmus indicus, Hygrophila phlomoides, Smilax glabra, $S$. prolifera, Stephania japonica and Terminalia arjuna of the studied area of North 24 Parganas district need conservation and also plantation for their important medicinal values.

\section{Acknowledgements:}

Thanks, are due to the Secretary, Department of Science and Technology, Govt. of West Bengal, India for financial assistance to carry out this project. We are also thankful to the Principal of Bangabasi College, Kolkata, West Bengal, India and to the Head of the Department of Botany, Kalyani University, Nadia, West Bengal, India for providing facilities during the work.

\section{References:}

1. Ambasta, S.P., Kmala Ramachandran, K. Kashyapa and Ramesh Chand. 1993. The Useful Plant of India, C.S.I.R., New Delhi.

2. Bhattacharyya, U.C. et al. 1997. Flora of West Bengal Vol. 1. B.S.I., Calcutta.

3. Dey, K.L.1896. The Indigenous Drugs of India, Calcutta (Rep. ed. 1984)

4. Hajra, P.K., R.R. Rao, D.K. Singh and B.P. Uniyal. 1995. Flora of India, Vols. XII \& XII. B.S.I., Calcutta.

5. Kirtikar, K.R. and B.D. Basu. 1918. Indian Medicinal Plants, Vols. I-IV, Allahabad, India (Rep. ed. 1981).

6. Sharma, B.D.N.P. Balakrishnan, R.R. Rao and P.K. Hajra. 1993. Flora of India, Vol. I.B.S.I. Calcutta and M Sanjappa. 1993. Flora of India, Vol. III. B.S.I., Calcutta.

7. Sivarajan, V.V. and Indira Balachandran. 1994. Ayurvedic Drugs and their Plants Sources, Calcutta.

8. Warrier, P.K., V. K.P. Nambiar and C. Ramankutty, 1993. Indian Medicinal Plants, Vol. I. Orient Longman, Madras. 